УДК 321.7.01: 340.15(045)

https://doi.org/10.52058/2708-7530-2022-1(19)-221-232

Прокопчук Ірина Іванівна кандидат політичних наук, доцент, доцент кафедри політології та соціології, Національний авіаційний університет, м. Київ, проспект Любомира Гузара 1, 03058, тел.: (050) 628-57-64, https://orcid.org/0000-0001-8473-5685

\title{
ЛІБЕРАЛЬНО-ДЕМОКРАТИЧНА ТЕОРІЯ ВЛАДИ АЛЕКСІСА ДЕ ТОКВІЛЯ (1805-1859)
}

Анотація В статті розглянута актуальна для українського сьогодення ліберально-демократична концепція влади видатного французького вченого та політичного діяча А. де Токвіля. Метою статті $\epsilon$ комплексний аналіз кратологічної теорії мислителя, що передбачає: 1) вивчення поглядів вченого на політику децентралізації та розвиток місцевого самоврядування; 2) аналіз токвілевих ідей щодо взаємовідносин держави та громадянського суспільства; 3) токвілеві підходи щодо поділу влади в середині громадянського суспільства; 4) узагальнення Токвіля щодо конструктивної та деструктивної ролі політичної опозиції в житті суспільства; 5) критика мислителем вождистських партій тоталітарного типу. Місцеве самоврядування Токвіль розглядав як джерело політичної свободи та першооснову демократії. Французький вчений в праці «Демократія в Америці» грунтовно проаналізував розподіл владних повноважень між центром і регіонами і високо оцінив політику децентралізації та самостійність громади. Розмежування сфер функціонування громадянського суспільства і держави вирішується вченим 3 позицій лібералізму, так званої теорії «держави нічного вартового» з акцентом на зовнішній стороні свободи. Вивчаючи особливості функціонування громадянського суспільства в США в 19 ст., Токвіль розглянув діяльність основних на той час політичних акторів: партій, асоціацій, преси. На прикладі американського суспільства свого часу вчений аргументовано проілюстрував конструктивну та деструктивну роль політичної опозиції (з боку партії, преси). Філософ передбачив та дослідив два політичних феномена - тоталітарна партія нового типу, що стала реалією у XX столітті і бюрократизація, олігархізація управління в партії.

Ключові слова: Токвіль, ліберально-демократична концепція влади, громадянське суспільство, місцеве самоврядування, політика децентралізації, політична опозиція, вождистські партії, преса.

Prokopchuk Iryna Ivanovna $\mathrm{PhD}$, Associate Professor of the Department of Sociology and Political Science, National Aviation University, Liubomyra Huzara Ave, 1, Kyiv,03058, tel.: (050) 628-57-64, https://orcid.org/0000-0001-8473-5685 


\section{LIBERAL DEMOCRATIC THEORY OF POWER OF ALEXIS DE TOCQUEVILLE (1805-1859)}

Abstract. This article offers a review of the liberal democratic concept of power by the outstanding French scientist and politician Alexis de Tocqueville, which has contemporary significance for today's Ukraine. The purpose of this article is to provide a comprehensive analysis of de Tocqueville's theory of power, which includes: 1) analysis of de Tocqueville's views of decentralization policy and development of local self-government; 2) analysis of de Tocqueville's ideas concerning the relationship between the state and civil society; 3 ) de Tocqueville's approaches to the division of power inside civil society; 4) de Tocqueville's generalizations concerning constructive and destructive role of political opposition in the society's life; 5) de Tocqueville's criticism of dictatorial parties of totalitarian type. The political philosopher regarded local self-government as a source of political freedom and the cornerstone of democracy. In his work Democracy in America, the French scientist thoroughly analyzed the division of political powers between the center and regions and highly praised decentralization policy and independence of communities. De Tocqueville proposes to divide the spheres of functioning of civil society and the state from the standpoint of liberalism, the socalled theory of a "night-watchman state" with the emphasis on the external side of freedom. When analyzing the functioning of civil society in the $19^{\text {th }}$ century United States, de Tocqueville considered the activity of the-then major subjects of politics: parties, associations, the press. Using the contemporary American society as an example, the political scientist illustrated, and substantiated, the constructive and destructive role of political opposition (on the part of parties and the press). The philosopher foresaw, and analyzed, two political phenomena: totalitarian party of new type, which became a reality in the $20^{\text {th }}$ century, and bureaucratization and oligarchization of administration within the party.

Keywords: de Tocqueville, liberal democratic concept of power, civil society, local self-government, decentralization policy, political opposition, dictatorial parties, the press.

Постановка проблеми. Трансформаційні процеси, що відбуваються протягом останніх тридцяти років в незалежній Україні гостро актуалізують потребу в теоретичному осмисленні проблеми реформування політичної влади, зокрема деетатизація суспільно-політичного життя, формування громадянського суспільства, розвиток місцевого самоврядування. Осмислення цих проблем можна знайти у творчій спадщині видатного французького вченого та політичного діяча А. де Токвіля. Токвіль був не тільки проникливим мислителем, а й професійним політиком: як депутат входив в комісію з розроблення проекту Конституції Другої республіки, був міністром закордонних справ, лідером політичної Партії порядку. 
Аналіз останніх досліджень і публікацій. Г.Дж.Ласкі звертає увагу на критику Токвілем державної влади 3 позицій класичного лібералізму. С ряд робіт, присвячених, впливу на державу окремих суб'єктів громадянського суспільства. Т.Б.Бекназар-Юзбашев, Ю.Маккарті, В.І.Терехов підкреслювали роль партій у становленні демократії у працях Токвіля. Р.Арон, Е.А.Іванян, Р.Рівс оцінювали токвілеві спостереження щодо преси як четвертої влади. Разом 3 тим, вищевказані автори лише намітили проблеми, які потребують подальшого грунтовного аналізу. Крім того поза увагою в науковій літературі залишилися питання взаємовідносин держави та громадянського суспільства, місцевого самоврядування, ролі опозиції у працях Токвіля.

Метою статті є комплексний аналіз кратологічної теорії А. де Токвіля, що передбачає: 1) вивчення поглядів вченого на політику децентралізації та розвиток місцевого самоврядування; 2) аналіз токвілевих ідей щодо взаємовідносин держави та громадянського суспільства; 3) токвілеві підходи щодо поділу влади в середині громадянського суспільства; 4) токвілеві узагальнення щодо конструктивної та деструктивної ролі політичної опозиції в житті суспільства; 5) критика Токвілем вождистських партій тоталітарного типу.

Виклад основного матеріалу. Описуючи політику децентралізації виконавчої гілки влади, мислитель звернув увагу на відсутність в середині неї жорсткої вертикалі. Верховна влада в США розподілена між урядом штату і федеральним. Ці «два уряди» повністю відокремлені один від одного і практично незалежні. Один 3 них носить самий звичайний характер, має досить широкі функції і забезпечує задоволення потреб суспільства. Тоді як другий, особливий. Сфера його діяльності обмежена i охоплює лише найзагальніші інтереси всієї країни. «Підтримувати розподіл влади між двома суперницькими урядами» покладено на федеральний Верховний суд [1,c.103]. Управління штатом здійснюється за принципом місцевого самоврядування. В справах, що стосуються компетенції штатів, вони залишаються самостійними та незалежними. Центральний уряд не мав права ні управляти ними, ні навіть контролювати їх дії. Це, природно, відкидає усяку одностайність та регламентацію в управлінні, які не відображають специфіки місцевих умов. Вдалість законів Токвіль визначав відповідністю духові народу і відсутністю необхідності пристосовуватися до законів, тому, що самі закони зовсім не враховують потреб і звичаїв людей. Це відобразилося на розподілі повноважень: конгрес приймає загальні закони, що регулюють життя суспільства, а місцеві законодавці займаються ними в деталях. Тому нерідко законодавство штатів відрізняється одне від одного і $є$ єдиним лише в загальних вихідних принципах. Об'єднавшись в федерацію, штати, по-перше, не втратили своєрідності, їхє населення «не перетворилося на єдиний народ», тобто не асимілювало, не стало гомогенним ані політично, ані духовно; по-друге, штати увійшли в федерацію на рівних умовах, і немає жодного, який займав би в них переважне місце і міг би вважати, що інші штати стоять нижче за нього, або залежать від нього.[1,с.269-270] 
Принцип організації влади на місцях в США - громадське самоврядування. Громадська незалежність, зазначав Токвіль, це «основа американської свободи і інструмент для пї впровадження в життя» [1,c.51]. Політичне життя в Америці розпочалося «не зверху офіційної піраміди» влади, як у Свропі, а саме з громади, первинного елемента політичного організму. Більше того громада не одержала владу ззовні, навпаки, вона сама немов би віддала частину своєї незалежності штату, федерації. Саме у громаді міститься сила вільних народів, оскільки вона «відкриває народу шлях до свободи i вчить його користуватися цією свободою, насолоджуючись іï мирним характером. Без громади нація може сформувати вільний уряд, однак справжнього духу свободи вона так і не здобуде», обмежуючись лише зовнішніми демократичними декораціями, вважав Токвіль [1,с.65].

Схематично затвердження політичної свободи в США проходило по наступним напрямкам: 1) розвиток громадянської активності і суверенітету індивідів та утворення на цій основі громад; 2) поступове виникнення великих адміністративних утворень (округ, штат , федерація ); 3) закріплення в законах традицій громади як звичної норми поведінки; 4) жорстке розмежування прав і координація обов'язків між громадою, з одного боку, і штатом, федерацією, 3 іншого.

Однак наївно сподіватись, що громадська незалежність може бути введена, як відзначав Токвіль, «прагненнями людей», хай навіть зацікавлених в ній, а тим більше в конкретно стиснути строки. По-перше, вона виникає ніби сама по собі, спонтанно: по-друге, недостатньо не тільки іiі директивного проголошення реформаторами і бажання їх прихильників підтримувати іiі. Лише при безперервній дії законів і звичаїв, обставин і особливо часу іiі вдається, врешті-решт, закріпити у суспільній практиці та у свідомості пересічних громадян [1,c.65]. Зміцненню громади сприяє також чітка правова регламентація функцій, сфер повноважень громади та органів штату, федерації, що протидіє дріб'язковій опіці, дублюванню функцій, скороченню місцевих ініціатив при одночасному розширенні прерогатив центральної влади. I хоча сфера діяльності громади обмежена, і вона не може вийти за іiі рамки, проте в середині цієї сфери громада цілковито вільна у своїх діях. «Штат править, але не управляє» громадою [1,с.80]. На укріпленні громади позначився і той факт, що навіть в середині неї існує «розмежування влади». 3 одного боку, це приваблює велику кількість людей до управління, 3 іншого, перешкоджає централізації і олігархізації влади на місцях, використанню іï у вузько-особистих цілях. Місцеве самоврядування як джерело політичної свободи приносить користь у різних формах правління. Але найбільшу цінність, за Токілем, воно набуває саме у демократичному суспільстві, оскільки: «Як же можна навчити масу людей користуватися свободою у великих справах, коли вони не звикли до неї в малих?» Тому, за Токвілем, ті, хто 3 однієї сторони, побоюються свавілля $\mathrm{i}$ анархії, а 3 іншої, гіперцентралізації влади, повинні разом прагнути до «поступового розвитку 
свободи на місцях» [1,с.90].

Питання розмежування сфер функціонування громадянського суспільства i держави вирішується вченим 3 позицій лібералізму, так званої теорії «держави нічного вартового» 3 акцентом на зовнішній стороні свободи. Мислитель державу визначав як «певну групу народних обранців, які зобов’язані представляти інтереси усього суспільства та здійснювати основний його закон-

справедливість. I тому чи повинні люди, «які представляють суспільство, бути більш могутніми, ніж саме суспільство, закон якого вони проводять у життя ?» [1,c.197] Токвіль відокремив суспільство від держави і визнав його первинність по відношенню до держави. Державу, як політичний інститут, мислитель, як і багато лібералів, сприймав обережно. Як зазначав Г. Дж. Ласкі, державну владу філософ вважав небезпечною річчю: чим менше в неї законних повноважень, тим менш ймовірна загроза тиранії з їі боку [2;с.10]. До того ж мислитель був переконаний, що об'єднана сила громадян завжди більш дієва, ефективна ніж урядова влада. Влада, якою б освіченою та вправною вона не була, не може одна охопити усі подробиці життя великого народу. Вона не спроможна цього зробити тому, що подібне завдання перевершує усі межі людських можливостей. Коли уряд робить спробу підмінити собою вільну участь безпосередньо зацікавлених у тій чи іншій справі людей, він повинен, або задовольнятися неповним результатом, або його зусилля будуть просто марні.

Урядові мислитель призначив доволі суворо визначені рамки: 1) керувати діяльністю поліції, що охороняє суспільство, припиняючи невеликі негаразди і незначні правопорушення, підтримувати суспільство в деякому статус-кво; 2) держава повинна будувати дороги, канали, порти, виконувати інші роботи, що мають суспільне значення; 3) Токвіль залишив за державою сферу політики і категорично заперечив роль уряду в економічній сфері. Однак він прозорливо відзначив, що роль держави буде посилюватися по мірі розвитку промисловості і зростання робітників, оскільки це виявляє такі соціальні проблеми: a ) різка поляризація суспільства між достатком і бідністю, що загрожує соціальним вибухом; б ) праця підриває здоров’я. Тому клас робітників вимагає більшої регламентації, контролю і стримування, ніж інші класи. Можливо вчений непрямо поставив проблему соціальної держави та соціальних прав ; 4 ) Токвіль негативно ставився до того, що уряд без потреби втручається в приватне життя громадян, хоче одноособово регулювати й всі менш вагомі види діяльності -

культуру, науку, освіту, виховання, доброчинність, з усіх сторін оточує громадян своїми «турботами», «порадами», «опікою», насаджуючи дух одноманітності, пересічності.

Ідеал вченого: приватні особи займаються дрібними турботами, а уряд виключно справами державного значення. Він вважав, що уряд не більш здатний стимулювати та поновлювати почуття та ідеї великого народу, ніж 
керувати промисловими підприємствами. Якщо уряд, за Токвілем, почне контролювати економіку, то сам того не бажаючи, почне насаджувати нестерпну тиранію тому, що уряд здатний лише диктувати жорсткі правила i положення. Мислитель визначав прямий зв'язок між свободою i промисловістю. «Воля надзвичайно сприяє виробництву матеріальних благ $\mathrm{i}$ суспільному розквіту».[3,с.372-373]

Описуючи розсередження політичної влади в межах американського суспільства, Токвіль використовував такі оціночні визначення політичного життя: «активне», «бурхливе», «повнокровне». Політичне життя громадянського суспільства реалізується в Америці через діяльність партій, багаточисельних об’єднань, преси, опозиції. Мислитель підкреслював різноманітність форм політичного життя. На його думку, найбільш природною для людини $є$ свобода діяти самостійно, поодинці. Наступним не менш природним кроком є об'єднання своїх зусиль із зусиллями собі подібних 3 метою сумісних дій. 3 цієї тези, що, на наш погляд, містить індивідуалістськокомуналістський підхід до тлумачення свободи, Токвіль виводить право на об’єднання у партії, асоціації, право меншості на опозицію. [4] Токвіль в цілому, як і Гоббс, Вашингтон, Медісон, Юмм, сприймав партії, як джерело криз та розбрату у суспільстві. Цікаво, що і визначення партії мислитель дав не 3 позиції об’єднання, а з точки зору роз'єднання. «Коли громадян країни роз'єднують різні погляди на проблеми, які цікавлять рівною мірою всі регіони країни, такі як ... загальні принципи державного правління, тоді виникають угрупування, які і називаються власне партіями». Партії, на його думку, «зло, властиве демократичному правлінню». За характером діяльності, цілями і принципами, вчений поділяв партії на «великі» і «малі» [1,c.144]. Т.Б.Бекназар-Юзбашев назвав це однією із спроб класифікації в партології [5,с.90]. «Великі» партії сповідують принципи докорінних перетворень політичного устрою суспільства. Їх більше цікавлять глобальні ідеї, а не «конкретні люди», теорія узагальнення, ніж практика. «Великі» партії виявляють колосальний вплив на все суспільство, здатні приводити до розколу у суспільстві та навіть струсу, однак тим самим нерідко і рятують його. «Малі» партії зароджуються і функціонують у періоди суспільної стабільності. Вони не ставлять перед собою великих цілей, іххн діяльність відрізняється швидше практицизмом і вирішенням конкретних завдань.

Наступним суб'єктом політичної влади в громадянському суспільстві $є$ асоціації. Токвіль один 3 перших у партології описав стадії виникнення i розвитку асоціацій: 1) спочатку людей об'єднують спільні погляди, між ними виникає чисто духовний зв'язок. Об'єднання веде рахунок своїм прихильникам і притягує все нових до свого кола; 2) члени об'єднання збираються разом, влаштовують збори. Політичне об'єднання розміщує свої осередки в ряді важливих точок країни, розширює коло своєї діяльності і розповсюджує свій вплив; 3 ) члени об'єднання при необхідності стають групою виборців і обирають серед своїх членів представників у центральну 
політичну організацію, тобто система представництва в середині однієї партії, або в державні органи.

Таким чином, вимальовується механізм легального приходу до влади через партії, політичні асоціації. Тому ми не поділяємо думку Г.Дж. Ласкі, що Токвіль так і не зрозумів структуру і значення партійної системи в США [2,c.15].

Токвіль високо оцінив політичні можливості асоціацій. Асоціації для нього - джерело громадянської свободи, оскільки здатні перешкоджати будьякому свавіллю з боку: влади партій, більшості, державних службовців, правителя i взагалі держави. Асоціації - засіб цивілізованої політичної боротьби, замість охлократичних форм протесту, якими є революції. Саме «повнокровне політичне життя» громадянського суспільства робить ідею необхідності асоціацій і бажання об'єднуватися частиною щоденних життєвих вражень громадян, тобто переходить в звичні форми політичної поведінки i участі. Вчений вражений , як вільно кожний день американці об'єднуються для того, щоб перемогла будь-яка політична думка, або ж з метою ввести в уряд будь-якого політичного діяча, а іншого позбавити влади. Асоціації цивілізований спосіб врегулювання політичного процесу. Проте у необмеженій свободі асоціацій в сфері політики не можна не бачити i негативні сторони, оскільки «якщо вона не веде народ до анархії, то постійно наближує до краю цієї прірви» [1,c.157]. I все ж, навіть викликавши час від часу струси у державі, свобода асоціацій сприяє подалі зміцненню суспільного спокою. Тому вміння створювати асоціації стає «першоосновою» суспільного життя, вважав Токвіль.

Наступною політичною силою в суспільстві $€$ преса. Токвіль один 3 перших мислителів, хто визнав за пресою - одним з перших засобів масової інформації - значну суспільну силу як в політиці, так i в утвердженні політичної свободи. «Преса, в першу чергу, $є$ демократичним знаряддям свободи» $[1 ;$ c.500]. «Незалежність преси це дещо фундаментальне , ... основна складова свободи» [1,c.156]. «Періодична преса ... є першою після народу силою» $[1, \mathrm{c.153]}$. «Вважаючи, що газети служать гарантією свободи, ми зменшили б їхне значення: вони підтримують існування самої цивілізації» [1,с.381]. Вчений не відмовляється від того, що в демократичних країнах газети часто призводять до досить нерозважливих сумісних дій, однак, якби не було газет, сумісні дії навряд чи були б можливі, бо газети на той період були єдиним джерелом інформації, комунікації та інтеграції суспільства.

Наступною значною силою громадянського суспільства виступає політична опозиція. В історії політико-правової думки до ролі опозиції в політичному житті звернулися ще до А. де Токвіля І. Бентам, Г.Болінгброк, Дж. Локк, Дж. Медісон. Якщо попередникі А. де Токвіля аналізували лише партійну опозицію, то французький вчений, описуючи американське плюралістичне суспільство, виокремив значно більше можливих суб'єктів політичної опозиції, виводячи останню 3 кулуарів лише партійно- 
парламентської боротьби і роблячи опозицію невід'ємною силою громадянського суспільства.

В демократичному суспільстві суб'єктами опозиції можуть бути партії, політичні асоціації, преса тощо. В аристократичному суспільстві часто опозиційну роль відігравала аристократія. Цікаво, що про позитивні наслідки влади, сили і впливу на суспільство партій, політичних асоціацій, преси, вчений згадував вельми скупо, мимохідь. Він акцентував увагу на можливих деструктивних проявах опозиції, приводячи, як ілюстрації, приклади з історії Америки і сучасні йому реалії. Слід відзначити, що самого слова «опозиція», описуючи політичні конфлікти в громадянському суспільстві, Токвіль не вживав. Ймовірно, саме можливі руйнівні впливи з боку партійної опозиції викликають у мислителя загалом негативні оцінки. Партії він називав «злом, притаманним демократичному правлінню», а також парламентському. Політична боротьба між федеральною партією і демократичною ніколи не доходила в Америці до жорстокості , як це траплялось в інших країнах. Це, на думку вченого, пов'язано з тим, що, по-перше, погляди і тих і інших на загальні питання співпадали, по-друге, для перемоги одного з них не потрібно було ані руйнувати старий порядок, ані змінювати суспільний устрій, тому бажання досягти перемоги своїх принципів не ставило під загрозу життя та свободу багатьох людей. Ні та, ні інша партія не виступали проти існуючої форми правління, не заперечувала проти поступового розвитку суспільства, опозиція не носила антисистемного характеру, так як був досягнутий консенсус стосовно загальних конституційних принципів та базових цінностей суспільно-політичного розвитку Америки. I все ж, вважає Токвіль, політична стабільність громадянського суспільства порушується, коли одна 3 партій в ході виборів приходить до влади. Тоді ця партія «руйнує усі перешкоди, виснажує свого супротивника і ставить все суспільство цілком собі на службу». Переможені у відчаї від такого успіху свого супротивника, припиняють свою діяльність. Скрізь настав спокій і тиша. Здається, що вся нація згуртувалася. Партія переможець робить наступну заяву: «Я поновила мир в країні, за це мені повинні платити по заслугах». Але за цією видимою одностайністю ховаються глибокі суперечки і реальний опір. Ось так і сталося в Америці: коли демократична партія здобула перевагу, суспільство стало свідком того, як вона заволоділа виключним правом керувати державними справами. 3 тих пір вона безперервно формує мораль і видає закони, виходячи iз своїх бажань» [1,с.147]. Можна казати, що у цьому достатньо проникливому опису політичного конфлікту між партіями, виявляється різка оцінка системи «гойдалки» в партійно-державному управлінні Америки, специфіки двопартійної системи, запозиченої, до речі, 3 Англії i відмінної від багатопартійної французької системи. Крім того контроль за діяльністю президента, уряду i парламенту у сучасному американському суспільстві розподіляється між двома партіями, що повинно знімати ідеологічну напругу та монополію однієї партії. I все ж можливість деструктивної опозиції, 
поляризації і подальшого розколу суспільства достатньо актуальна, особливо для суспільства, яке, не звикло користуватися свободою і охоплено глибокими політичними пристрастями. Для таких народів мислитель передбачав часи, коли нація майже порівну розподілена між двома впливовими партіями, кожна з яких претендує на те, що саме вона представляє більшість нації. Тоді поряд 3 правлячою партією затверджується інша, моральний авторитет якої майже такий же. Чи можливо, щоб ця остання довгий час приймала участь тільки в обговоренні законів, не вдаючись до дій? Чи зупинить іï таке метафізичне міркування, що метою об’єднання є вплив на суспільну думку, а не примушення ऑï, внесення пропозицій до закону, що виробляється, а не створення самого закону? Хоча така ситуація створює небезпеку політичній стабільності і суспільному порядку, Токвіль, як Актон, Медісон та інші залишив за опозиційною меншістю право об’єднувати свої зусилля, роблячи вибір між великим і малим злом. Коли будь-яка партія стає правлячою, вся

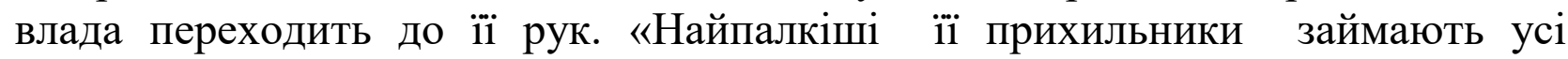
відповідні пости, в їхньому розпорядженні виявляються і всі адміністративні структури. Провідні діячі іншої партії, які залишаються поза коридорами влади, повинні мати право об’єднати свої зусилля, і ця меншість повинна мати можливість протиставити владі, яка їх стане обмежувати, силу морального впливу на маси» [1,с.157]. Саме відсутність практики користування свободою як такою призводить людей до зловживання свободою, в тому числі свободою об'єднуватися, перетворюючи іiі iз «животворної сили в силу руйнівну». Токвіль порівнював розуміння функцій політичної опозиції та права на об’єднання в Америці і в Європі. Аналізуючи суспільне життя США, філософ наблизився до сучасного розуміння наступних функцій політичної опозиції: інтегруюча, критична, конструктивна [1,с.158]. «В Америці члени об’єднання, що складають меншість, насамперед хочуть знати скільки їх, тому, що їхня найперша мета послабити моральні дії більшості» (інтегруюча функція опозиції). Щоб досягти влади необхідно просто стати на чолі більшості, схиливши іiі на свій бік. «Друга мета виявити всі можливості, які могли б використані для здійснення тиску на більшість» (критична функція опозиції). «Їхня кінцева мета привернути на свою сторону більшість i, таким чином, стати при владі». На думку вченого, в США опозиційні політичні організації мирні і користується в своїй боротьбі лише законними засобами. Такі організації в очах іiі громадян є меншістю народу, а тому вони займаються створенням i обговоренням петицій (конструктивна функція опозиції). Повноцінне функціонування інституту опозиції - одну з рис американської політичної культури - Е. Баталов назвав установкою на сприйняття політичного конфлікту як норми та виведення його на поверхню у легальну площину [6,c.232]. У Європі, за Токвілем, опозиція нерідко має антисистемний, деструктивний характер, бо $є$ партії, які не виражають інтереси більшості, однак достатньо сильні, щоб боротися проти більшості. Тому їхня політична організація ставить на меті не переконувати, а 
перемагати. В Свропі багато партій, які претендують на легітимність, тобто широку масову підтримку, прагнуть виступати від імені народу, який, на їхню думку, сам по собі виступати не може. Тому вони діють і командують. «Ці претензії», можна, навіть сказати, ця впевненість дуже сильно сприяє укріпленню їхнього положення у державі і служить чудовим виправданням дій, що розпочинаються за ним. Хіба не пробачиться застосування сили заради перемоги справи, пов'язаної з боротьбою за конкретні права та свободи ?

Будучи гуманістом, Токвіль не міг не торкнутися проблеми цілей i засобів в політиці при досягненні певних загальнолюдських ідеалів: свободи, рівності, демократії, миру, добробуту, справедливості. На думку вченого, в Європі засоби, якими користуються опозиційні політичні організації, відповідають тій меті, яку вони ставлять перед собою. Загальна мета цих організацій діяти, а не розмірковувати, боротися, а не переконувати. Природно, що в результаті вони прийшли до такого типу «організації, яка аж ніяк не схожа на громадську: норма поведінки іi членів і лексика, яку вони використовують, запозичені у військових, побудовані ці організації за принципом централізму, - керівництво всіма їхніми силами знаходиться на верхній ступені і влада сконцентрована в руках невеличкої групи людей. Члени цих організацій реагують на кожний наказ, як солдати в період війни; вони визнають лише догму пасивної покори» [1,c.159]. На думку Токвіля, об'єднавшись, вони немов би разом відмовилися від свого власного міркування, і від своєї власної волі. В рядах цих організацій нерідко панує тиранія, ще більш нестерпна, ніж тиранія уряду, з яким вони борються. На наш погляд, вчений передбачив два політичних феномена -тоталітарна партія нового типу, що стала реалією у XX столітті і бюрократизація , олігархізація управління в партії («залізний закон олігархії» Р. Міхельса) [7]. Крім деструктивної ролі партій у суспільному житті Токвіль змальовує деструктивну роль політиків - демагогів, описуючи узагальнений портрет політичного лідера-політикана. «Головні обов’язки керманича політичної партії полягають у наступному: постійно вступати у зв'язки 3 іншими прибічниками та навіть із своїми супротивниками, щодня бути на виду, щохвилини то принижуватися, то підвищувати себе для того, щоб досягти однакового рівня 3 іншими представниками інтелігенції, розмірковувати та наводити докази без відпочинку, тисячу разів повторювати одне й те ж саме у різних формах та постійно захоплюватися при виді одного й того ж предмету» . Крім того, ці люди наділені «дорогоцінною та навіть нерідко необхідною для політичного діяча здібністю створювати для себе тимчасові переконання згідно 3 їх пристрастями та мінливими інтересами, цим способом вони отримують можливість доволі чесно здійснювати не зовсім чесні справи» [8,с.93,с.95]. Токвіль підкреслює, що бачив не мало подібних політиканів, що «приречені своїми чеснотами на страждання та впали у відчай від того, що вони проводили кращі роки свого життя у критиці чужих вад, не маючи можливості насолоджуватися своїми власними і обмежуючись лише 
спостеріганням зловживань! Впродовж цього тривалого утримання в них розвивалася така жадібність до посад, до почестей та грошей, що вони були готові при першій ліпшій нагоді прийняти на себе будь-яку офіційну посаду, не вишукуючи зручної для цього хвилини та подібно до ненажер не розбираючи, чи добрий потрапив їм у рот шматок» [8,с.104].

Деструктивну опозиційну роль в суспільстві може відігравати і преса. Необмежена свобода преси менш безпечна, ніж необмежене право на об’єднання в партії і асоціації. Однак преса може мати не менш руйнівні схильності. «Неприборканість преси» мислитель не пов’язував 3 «соціальною нестабільністю», «політичними пристрастями», загальним неспокоєм. «Свобода писати, також як і решта свобод, тим більш небезпечна, чим пізніше вона 3'явилася i нещасні покоління, які першими впровадили свободу друку!» [1,c.153]. Токвіль цитує газету з критикою тогочасного президента Сндрю Джексона: «Амбіції - це його злочин, і це саме буде його ж покаранням. Його покликання - інтриги, і інтриги поламають усі його плани и вирвуть владу 3 його рук. Він править за допомогою корупції, і його злочинні махінації обернуться для нього на сором та ганьбу. Він зарекомендував себе на політичній арені як гравець без честі та гальм. Він домігся неабиякого успіху, але година справедливості наближається; невдовзі він муситиме повернути все, що нагарбав, далеко пожбурити свою гральну кістку й піти у відставку, де він матиме змогу досхочу проклинати своє безглуздя; бо його серце ніколи не знало такої чесноти, як каяття» [1,c.149]. Дійсно критика американськими 3МI високопосадовців стала своєрідною традицією в США [9,с.98]. [10,с.18-19, 27, 38, 47].

Висновки. Підсумовуючи, слід визначити, що по-перше, на відміну від попередників Дж. Локка та Ш. Монтескє А. де Токвіль принципи децентралізації переніс взагалі на будь-яку владу, не тільки традиційно поділяючи державну владу по горизонталі та по вертикалі, а й обгрунтовуючи розмежування політичної влади за сферою функціонування (державна i влада громадянського суспільства), «розпорошення влади» в середині самого громадянського суспільства, описуючи багато «центрів» i «точок» політичного впливу на державу з боку партій, асоціації, преси, чим виявив вплив на теорію поліархії Р. Даля, «розпорошення» влади на рівні навіть місцевого самоврядування. По-друге, у вченні про владу Токвіля принципи поділу державної влади гармонійно спиралися на ідею народного суверенітету.

\section{Jimepamypa:}

1.Токвиль Алексис де. Демократия в Америке: Пер. с франц. М.: Прогресс, 1992. 554 с.

2. Ласки Г. Дж. Предисловие. Токвиль А. де. Демократия в Америке: Пер. с франц. М.: Прогресс, 1992 . с. 5 - 23 .

3. Tocqueville A de. Mellanges fragments historiques et notes sur l'ancien regim, la revolution, et le'mpIre. Voyages-Pensees. Entierement inedits de Tocqueville. Oeuvres completes d'A de Tocqueville le publiees par madame de Tocqueville. Vol. YIII . Paris, 1865. 
4. Прокопчук I.I. Сутність та структура свободи.Людина і політика. 2000. №1. с.30-35.

5. Бекназар-Юзбашев Т. Б. Партии в буржуазных политико-правовых учениях . М.: Наука, 1988. 174 с.

6. Баталов Э.Я. Политическая культура современного американского общества . М.: Наука, 1990. 255 с.

7. Михельс Р. Социология политической партии в условиях демократии. Личность. Культура. Общество.2002.Том ІУ.Вып 3-4 (13-14).с.214-228.

8. Воспоминания Алексиса Токвиля: Пер с франц. М.: Изд. К.Т.Солдатенкова, 1893. 319 с.

9. Гаджиев К. С. Американская нация : Национальное самосознание и культура . М.: Наука, 1990. 239 с.

10. Иванян Э. А. От Джорджа Вашингтона до Джорджа Буша: Белый дом и пресса. М.: Политиздат, 1991.368 с.

\section{References:}

1.Tokvil', Aleksis de. (1992). Demokratija v Amerike [Democracy in America]. M.: Progress [in Russian].

2. Laski, G. Dzh. (1992). Predislovie. Tokvil' A. de. Demokratija v Amerike [Preface. Tocqueville A. de. Democracy in America]. M.: Progress [in Russian].

3. Tocqueville A de. Mellanges fragments historiques et notes sur l'ancien regim, la revolution, et le'mpIre. Voyages-Pensees. Entierement inedits de Tocqueville. Oeuvres completes d'A de Tocqueville le publiees par madame de Tocqueville. Vol. YIII . Paris, 1865.

4. Prokopchuk, I.I. (2000). Sutnist' ta struktura svobodi [The essence is the structure of freedom]. Ljudina i politika - People and politics, 1, .30-35 [in Ukrainain].

5. Beknazar-Juzbashev, T. B. (1988). Partii v burzhuaznyh politiko-pravovyh uchenijah [Parties in bourgeois political and legal doctrines]. M.: Nauka [in Russian].

6. Batalov, Je.Ja. (1990). Politicheskaja kul'tura sovremennogo amerikanskogo obshhestva [The Political Culture of Modern American]. M.: Nauka [in Russian].

7. Mihel's, R. (2002). Sociologija politicheskoj partii v uslovijah demokratii [Sociology of a political party in a democracy]. Lichnost'. Kul'tura. Obshhestvo - Personality. Culture. Society, 3-4 (13-14), 214-228 [in Russian].

8. Vospominanija Aleksisa Tokvilja [Memoirs of Alexis Tocqueville]. M.: Izd. K.T.Soldatenkova [in Russian].

9. Gadzhiev, K. S. (1990). Amerikanskaja nacija : Nacional'noe samosoznanie i kul'tura [American Nation: National Self-Consciousness and Culture]. M.: Nauka [in Russian].

10. Ivanjan, Je. A. (1991). Ot Dzhordzha Vashingtona do Dzhordzha Busha: Belyj dom i pressa [From George Washington to George Bush: The White House and the Press]. M.: Politizdat [in Russian]. 